\title{
Net energy of corn, soybean meal and rapeseed meal in growing pigs
}

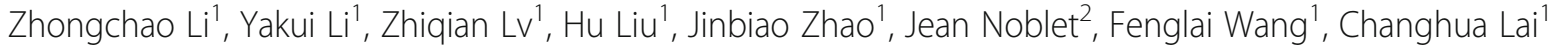 \\ and Defa $\mathrm{Li}^{1 *}$
}

\begin{abstract}
Background: Two experiments were conducted to estimate the net energy (NE) of corn, soybean meal, expeller-pressed rapeseed meal (EP-RSM) and solvent-extracted rapeseed meal (SE-RSM) using indirect calorimetry and to validate the NE of these four ingredients using pig growth performance.

Methods: In Exp.1, 24 barrows (initial BW $=36.4 \pm 1.6 \mathrm{~kg}$ ) were allotted to 1 of 4 diets which included a corn basal diet, a corn-soybean meal basal diet and two rapeseed meal diets containing 20\% EP-RSM (9.5\% ether extract) or SE-RSM (1.1\% ether extract) substituted for corn and soybean meal. The design allowed the calculation of NE values of corn, soybean meal and rapeseed meals according to the difference method. In Exp.2, 175 growing pigs (initial BW = 36.0 $\pm 5.2 \mathrm{~kg}$ ) were fed 1 of 5 diets for $28 \mathrm{~d}$, with five pigs per pen and seven replications (pens) per treatment in order to validate the measured energy values. Diets were a corn-soybean meal diet and four diets including 10\% or 20\% EP-RSM and $10 \%$ or $20 \%$ SE-RSM.
\end{abstract}

Results: The NE of corn, soybean meal, EP-RSM and SE-RSM were 12.46, 11.34, 11.71 and $8.83 \mathrm{MJ} / \mathrm{kg} \mathrm{DM}$, respectively. The NE to ME ratio of corn (78\%) was similar to tabular values, however, the NE to ME ratios of soybean meal (70\%) and rapeseed meal (76\%) were greater than tabular values. The greater NE value in EP-RSM than in SE-RSM is consistent with its higher EE content. Increasing EP-RSM or SE-RSM did not affect the growth performance of pigs and the caloric efficiency of NE was comparable for all diets.

Conclusions: The NE of EP-RSM was similar to soybean meal, and both were greater than SE-RSM. The DE, ME and NE values measured in Exp.1 are confirmed by results of Exp. 2 with comparable caloric efficiencies of $D E, M E$ or NE for all diets.

Keywords: Caloric efficiency, Growing pig, Heat production, Net energy, Rapeseed meal

\section{Background}

Following soybean, the most abundant oilseed produced in the world is rapeseed, with a production of about 70 million tons in 2015 [1]. There are two primary rapeseed co-products associated with oil extraction processing methods: expeller-pressed rapeseed meal (EP-RSM) containing $10 \%$ to $15 \%$ residual oil and solvent-extraction rapeseed meal (SE-RSM) containing much less oil (1-2\%) than EP-RSM. In a previous work, the DE, ME and standardized ileal digestible (SID) amino acid (AA) of SERSM [2] and EP-RSM [3] were evaluated. Little et al. [4]

\footnotetext{
* Correspondence: defali@cau.edu.cn

${ }^{1}$ State Key Laboratory of Animal Nutrition, Ministry of Agriculture Feed Industry Centre, China Agricultural University, No. 2, Yuanminyuan west road, Haidian district, Beijing 100193, China

Full list of author information is available at the end of the article
}

found high-protein or conventional rapeseed meal may fully replace soybean meal as protein supplements in growing-finishing pig diets without impairing pig performance or carcass quality. However, there are limited reports that estimate and compare the NE of EP-RSM and SE-RSM or that have validated the NE value of rapeseed meals using a growth trial. In addition, there is no clear agreement on the proper method of validation of energy values using growth trials. Some researchers have proposed the concept of caloric efficiency [5-8] meaning that, if the assigned energy value is correct, regardless of the test ingredient inclusion level, a similar caloric efficiency (ie, dietary energy per $\mathrm{kg}$ of BW gain) will be calculated among the dietary treatments. However, in these experiments, the NE value of corn and soybean meal, which are the two main 
ingredients in the formula, were referenced from tabular values. However, in the current experiment, we have measured the NE of all ingredients in a first experiment (Exp. 1) and used the obtained values in a second validation experiment (Exp. 2). Practically, the NE of corn, soybean meal, EP-RSM and SE-RSM were determined by indirect calorimetry and these four ingredients were used subsequently to prepare five diets fed in a growth trial.

\section{Methods}

The two experimental protocols used in this study were approved by the Institutional Animal Care and Use Committee of China Agricultural University (Beijing, China).

\section{Exp.1: Net energy experiment}

Twenty-four barrows (Duroc $\times$ Large White $\times$ Landrace, initial $\mathrm{BW}=36.4 \pm 1.6 \mathrm{~kg}$ ) were used in this experiment conducted at the FengNing Swine Research Unit of China Agricultural University (Hebei Province, China). The 24 barrows were allotted to 1 of 4 dietary treatments with six pigs per diet and four periods. Diets included a corn basal diet supplemented with free amino acids in order to improve the amino acids balance of corn and maximize protein gain, a corn-soybean meal basal diet (to calculate the energy of soybean meal using the difference method), and two rapeseed meal diets containing 20\% EPRSM or SE-RSM substituted for corn and soybean meal (to calculate the energy of rapeseed meals using the difference method). The analyzed nutrient composition of ingredients are shown in Table 1. The ratios between SID essential amino acids and SID Lys met or exceeded the recommended amino acid ratios (NRC 2012) in all diets; but the amino acids content in the corn diet was below the standard recommendations for growing pigs (Table 2).

During each period, pigs were individually housed in metabolism crates for $16 \mathrm{~d}$, which included seven initial days to adapt to the feed, metabolism crate and environmental conditions. On d 8, the pigs were transferred to the open-circuit respiration chambers $[9,10]$ for measurement of daily $\mathrm{O}_{2}$ consumption and $\mathrm{CO}_{2}$ and $\mathrm{CH}_{4}$ productions. During this time, pigs were fed one of the four diets at 2,200 kJ ME $/\left(\mathrm{kg} \mathrm{BW}^{0.6} \cdot \mathrm{d}\right)$. Total feces and urine were collected from d 9 to $\mathrm{d} 13$; gas exchanges were measured over the same period for calculating heat production (HP). On d 14 and 15, pigs were fed at their maintenance requirement level $\left(890 \mathrm{~kJ} \mathrm{ME} /\left(\mathrm{kg} \mathrm{BW}^{0.6} \cdot \mathrm{d}\right)\right.$ [9] in order to adapt them from the fed to the fasted state. HP was also measured at this low feed level, but the results are not included in the present paper. On the last day of each period (d 16), pigs were fasted; the HP measured during the last $8 \mathrm{~h}$ of d 16 from $2230 \mathrm{~h}$ (d 16) to $0630 \mathrm{~h}$ (d 17) was considered as fasting heat production (FHP). The FHP period started then $31 \mathrm{~h}$ after the last meal and always in the dark with expected minimal physical activity.
Table 1 Analyzed nutrient composition of ingredients used in the experiment $\left(\%\right.$, DM basis) ${ }^{a}$

\begin{tabular}{|c|c|c|c|c|}
\hline Item & Corn & SBM & EP-RSM & SE-RSM \\
\hline$\overline{\mathrm{GE}}, \mathrm{MJ} / \mathrm{kg}$ & 18.44 & 19.50 & 21.33 & 19.54 \\
\hline Crude protein & 9.2 & 48.5 & 39.2 & 42.4 \\
\hline Ether extract & 3.0 & 1.2 & 9.5 & 1.1 \\
\hline NDF & 14.0 & 17.1 & 37.0 & 30.8 \\
\hline ADF & 2.5 & 10.0 & 22.8 & 20.7 \\
\hline Ash & 1.2 & 6.2 & 6.4 & 7.0 \\
\hline \multicolumn{5}{|c|}{ Indispensable AA } \\
\hline Arg & 0.39 & 3.81 & 2.75 & 2.64 \\
\hline His & 0.24 & 1.46 & 1.27 & 1.27 \\
\hline Leu & 1.13 & 3.82 & 2.84 & 2.93 \\
\hline Ile & 0.27 & 2.14 & 1.50 & 1.59 \\
\hline Lys & 0.28 & 3.23 & 2.70 & 2.57 \\
\hline Met & 0.16 & 0.57 & 0.75 & 0.77 \\
\hline Phe & 0.41 & 2.46 & 1.52 & 1.41 \\
\hline Thr & 0.36 & 2.12 & 1.77 & 1.89 \\
\hline Trp & 0.06 & 0.61 & 0.61 & 0.65 \\
\hline Val & 0.42 & 2.34 & 2.03 & 2.14 \\
\hline \multicolumn{5}{|l|}{ Dispensable AA } \\
\hline Ala & 0.65 & 2.25 & 1.91 & 1.98 \\
\hline Asp & 0.62 & 5.74 & 2.82 & 2.97 \\
\hline Cys & 0.17 & 0.63 & 0.95 & 0.95 \\
\hline Glu & 1.69 & 8.77 & 7.18 & 7.31 \\
\hline Gly & 0.32 & 2.21 & 2.14 & 2.22 \\
\hline Pro & 0.86 & 2.72 & 2.86 & 2.92 \\
\hline Ser & 0.45 & 2.54 & 1.72 & 1.83 \\
\hline Tyr & 0.31 & 1.66 & 1.02 & 0.93 \\
\hline
\end{tabular}

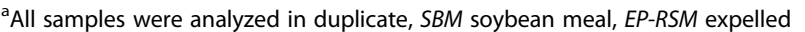
press rapeseed meal, $S E-R S M$ solvent extracted rapeseed meal

Pigs were fed equal size meals twice daily at $15 \div 30$ and $1530 \mathrm{~h}$ and had free access to water via a low-pressure nipple drinker throughout the trial. The chambers were opened for approximately $1 \mathrm{~h}$ per day at 0830 and $1530 \mathrm{~h}$ to feed the pigs and collect the feces. The $\mathrm{O}_{2}$ consumption and $\mathrm{CO}_{2}$ and $\mathrm{CH}_{4}$ productions during this time were not included in the calculation of daily HP. The concentration of $\mathrm{CO}_{2}$ in the chamber increased when the door was closed. The calculation of HP began when the concentration of $\mathrm{CO}_{2}$ in the chamber was above 2,000 ppm [10].

During $\mathrm{d} 9$ to $\mathrm{d} 13$, feed refusals and spillage were collected twice daily and dried and weighed. Total but separate collections of feces and urine were conducted according to the methods described by Li et al. [10]. Feces were collected twice daily at 0830 and $1530 \mathrm{~h}$ when the chamber door was opened and immediately stored at $-20^{\circ}$ C. Urine was collected each morning at $0830 \mathrm{~h}$ for each pig from plastic buckets containing $50 \mathrm{~mL}$ of $6 \mathrm{~N} \mathrm{HCl}$ and 
Table 2 Ingredients and chemical composition of the Exp.1 diets $^{a}$

\begin{tabular}{|c|c|c|c|c|}
\hline Diet & Corn & SBM & EP-RSM & SE-RSM \\
\hline \multicolumn{5}{|l|}{ Ingredients, \% } \\
\hline Corn & 97.03 & 77.13 & 61.31 & 61.31 \\
\hline Soybean meal & - & 20.00 & 15.90 & 15.90 \\
\hline EP-RSM & - & - & 20.00 & 0.00 \\
\hline SE-RSM & - & - & - & 20.00 \\
\hline Dicalcium phosphate & 0.90 & 0.90 & 0.90 & 0.90 \\
\hline Limestone & 0.75 & 0.75 & 0.75 & 0.75 \\
\hline Salt & 0.35 & 0.35 & 0.35 & 0.35 \\
\hline Vitamins and minerals premix ${ }^{b}$ & 0.50 & 0.50 & 0.50 & 0.50 \\
\hline Lys-HCl & 0.26 & 0.21 & 0.16 & 0.16 \\
\hline DL-Met & 0.14 & 0.11 & 0.09 & 0.09 \\
\hline L-Thr & 0.03 & 0.02 & 0.02 & 0.02 \\
\hline L-Trp & 0.04 & 0.03 & 0.03 & 0.03 \\
\hline $\mathrm{DM}, \%$ & 86.69 & 86.93 & 87.95 & 87.27 \\
\hline \multicolumn{5}{|l|}{ Analyzed composition, DM basis } \\
\hline$C P, \%$ & 9.3 & 17.2 & 21.4 & 22.5 \\
\hline $\mathrm{EE}, \%$ & 2.9 & 2.8 & 4.0 & 2.3 \\
\hline$N D F, \%$ & 12.8 & 16.7 & 21.8 & 18.7 \\
\hline$A D F, \%$ & 3.0 & 4.6 & 7.9 & 7.3 \\
\hline Ash, \% & 3.4 & 4.4 & 5.2 & 5.3 \\
\hline $\mathrm{GE}, \mathrm{MJ} / \mathrm{kg}$ & 18.12 & 18.23 & 18.73 & 18.36 \\
\hline \multicolumn{5}{|l|}{ Calculated composition } \\
\hline SID Lys & 0.38 & 0.80 & 0.99 & 0.98 \\
\hline SID Thr/SID Lys & 0.70 & 0.65 & 0.65 & 0.67 \\
\hline SID Trp/SID Lys & 0.22 & 0.20 & 0.21 & 0.22 \\
\hline SID Val/SID Lys & 0.78 & 0.72 & 0.74 & 0.76 \\
\hline SID Leu/SID Lys & 2.21 & 1.55 & 1.41 & 1.43 \\
\hline SID lle/SID Lys & 0.50 & 0.60 & 0.61 & 0.61 \\
\hline SID His/SID Lys & 0.45 & 0.44 & 0.47 & 0.47 \\
\hline SID Met + Cys/SID lys & 0.98 & 0.59 & 0.63 & 0.64 \\
\hline SID Phe + Tyr/SID Lys & 1.34 & 1.29 & 1.20 & 1.17 \\
\hline
\end{tabular}

${ }^{a}$ All samples were analyzed in duplicate, SBM, soybean meal; EP-RSM, expelled press rapeseed meal; $\mathrm{SE}-\mathrm{RSM}$, solvent extracted rapeseed meal

${ }^{b}$ Vitamin-mineral premix supplied the following per $\mathrm{kg}$ of diet: vitamin $A$, 5,512 IU; vitamin $\mathrm{D}_{3}, 2,200 \mathrm{IU}$; vitamin $\mathrm{E}, 30 \mathrm{IU}$; vitamin $\mathrm{K}_{3}, 2.2 \mathrm{mg}$; vitamin $\mathrm{B}_{12}$ $27.6 \mu$; riboflavin, $4 \mathrm{mg}$; pantothenic acid, $14 \mathrm{mg}$; niacin, $30 \mathrm{mg}$; choline chloride, $400 \mathrm{mg}$; folic acid, $0.7 \mathrm{mg}$; thiamine, $1.5 \mathrm{mg}$; pyridoxine, $3 \mathrm{mg}$; biotin, $44 \mu \mathrm{g} ; \mathrm{Mn}(\mathrm{MnO}), 40 \mathrm{mg} ; \mathrm{Fe}\left(\mathrm{FeSO}_{4} \cdot \mathrm{H}_{2} \mathrm{O}\right), 75 \mathrm{mg} ; \mathrm{Zn}(\mathrm{ZnO}), 75 \mathrm{mg} ; \mathrm{Cu}$ (CuSO $\left.{ }_{4} \cdot 5 \mathrm{H}_{2} \mathrm{O}\right), 100 \mathrm{mg}$; I (KI), $0.3 \mathrm{mg} ; \mathrm{Se}\left(\mathrm{Na}_{2} \mathrm{SeO}_{3}\right), 0.3 \mathrm{mg}$

filtered through cotton gauze. The total urinary volume produced by each pig was measured and $5 \%$ of the daily urinary excretion was stored at $-20{ }^{\circ} \mathrm{C}$. At the end of the urinary collection, urine samples were thawed, and thoroughly mixed, and a sub-sample was saved for analysis. Urine was collected separately during the $24 \mathrm{~h}$ fasting state to calculate urinary nitrogen $(\mathrm{N})$ losses for the calculation of FHP.
At the end of the experiment, fecal samples were thawed, mixed, weighed, and sub-samples were ovendried for $72 \mathrm{~h}$ at $65{ }^{\circ} \mathrm{C}$ for measurement of dry matter fecal excretion. The feed and fecal samples were ground through a 1-mm screen prior to chemical analysis. Six chambers were available for the current experiment. Therefore, Exp. 1 was conducted at four consecutive periods; the experimental design is detailed in the Table 7 in Appendix.

\section{Exp.2: Growth performance experiment}

A total of 175 growing pigs (initial BW $=36.0 \pm 5.2 \mathrm{~kg}$ ) were fed 1 of 5 diets for $28 \mathrm{~d}$, with five pigs per pen and seven replications (pens) per treatment. Diets were a corn-soybean meal based diet and diets including 10\% or $20 \%$ EP-RSM and 10 or $20 \%$ SE-RSM (Table 3). All ingredients in Exp. 2 (corn, SBM, EP-RSM and SERSM) were the same as in Exp. 1; the NE values of diets in Exp. 2 were calculated according to the results of Exp. 1 and the ratio between SID Lys and NE value was the same among the five diets. The ratio between SID essential amino acids and SID Lys met the ideal protein profile. Pigs had free access to feed and water throughout the experiment; room temperature was maintained between 22 and $24{ }^{\circ} \mathrm{C}$.

\section{Chemical analyses and calculations}

Ingredients, diets and feces were analyzed for dry matter (DM) (AOAC 2007, 930.15), crude protein (CP) (AOAC 2007, 984.13), ash (AOAC 2007, 942.05) [11], and ether extract (EE) [12]. The organic matter (OM) was calculated as DM minus ash content. Neutral detergent fiber (NDF) and acid detergent fiber (ADF) were determined using filter bags and fiber analyzer equipment (Fiber Analyzer, Ankom Technology, Macedon, NY) following a modification of the procedure of Van Soest et al. [13]. The gross energy (GE) was analyzed using an isoperibol calorimeter (Parr 6300 Calorimeter, Moline, IL) with benzoic acid as a standard.

The ingredients were hydrolyzed with $6 \mathrm{~N} \mathrm{HCl}$ at $110{ }^{\circ} \mathrm{C}$ for $24 \mathrm{~h}$ and analyzed for 15 amino acids using an Amino Acid Analyzer (Hitachi L-8900, Tokyo, Japan). Methionine and cysteine were determined as methionine sulfone and cysteic acid after cold performic acid oxidation overnight and hydrolyzing with $7.5 \mathrm{~N} \mathrm{HCl}$ at $110{ }^{\circ} \mathrm{C}$ for $24 \mathrm{~h}$ using an Amino Acid Analyzer (Hitachi L-8800, Tokyo, Japan). Tryptophan was determined after $\mathrm{LiOH}$ hydrolysis for $22 \mathrm{~h}$ at $110{ }^{\circ} \mathrm{C}$ using HPLC (Agilent 1200 Series, Santa Clara, CA, USA).

In Exp.1, the DM intake from d 9 to $\mathrm{d} 13$ in each period was calculated as the product of feed intake and DM content of diets. GE intake was calculated as the product of the GE content of the diet and the actual feed 
Table 3 Ingredients and chemical composition of the Exp.2 diets ${ }^{a}$

\begin{tabular}{|c|c|c|c|c|c|}
\hline \multirow[t]{2}{*}{ Diets } & \multirow[t]{2}{*}{ Basal } & \multicolumn{2}{|c|}{ EP-RSM } & \multicolumn{2}{|c|}{ SE-RSM } \\
\hline & & $10 \%$ & $20 \%$ & $10 \%$ & $20 \%$ \\
\hline \multicolumn{6}{|l|}{ Ingredients, \% } \\
\hline Corn & 76.64 & 69.24 & 61.82 & 69.35 & 62.01 \\
\hline Soybean meal & 20.00 & 18.00 & 16.00 & 18.00 & 16.00 \\
\hline EP-RSM & - & 10.00 & 20.00 & - & - \\
\hline SE-RSM & - & - & - & 10.00 & 20.00 \\
\hline Dicalcium phosphate & 0.60 & 0.40 & 0.35 & 0.45 & 0.35 \\
\hline Limestone & 0.75 & 0.75 & 0.60 & 0.70 & 0.60 \\
\hline Salt & 0.35 & 0.35 & 0.35 & 0.35 & 0.35 \\
\hline Vitamin and mineral premix ${ }^{b}$ & 0.50 & 0.50 & 0.50 & 0.50 & 0.50 \\
\hline Lys-HCl & 0.50 & 0.36 & 0.22 & 0.33 & 0.16 \\
\hline Met & 0.20 & 0.12 & 0.05 & 0.10 & 0.03 \\
\hline Thr & 0.18 & 0.11 & 0.05 & 0.09 & 0.00 \\
\hline Trp & 0.07 & 0.04 & 0.01 & 0.03 & 0.00 \\
\hline Val & 0.21 & 0.13 & 0.05 & 0.10 & 0.00 \\
\hline \multicolumn{6}{|l|}{ Calculated composition } \\
\hline $\mathrm{CP}$ & 15.67 & 17.51 & 19.35 & 17.60 & 19.57 \\
\hline $\mathrm{Ca}$ & 0.53 & 0.53 & 0.52 & 0.53 & 0.52 \\
\hline STTD P & 0.26 & 0.24 & 0.26 & 0.25 & 0.25 \\
\hline $\mathrm{DE}^{\mathrm{C}}$ & 14.25 & 14.28 & 14.32 & 13.92 & 13.59 \\
\hline$M E^{c}$ & 13.75 & 13.76 & 13.77 & 13.37 & 12.99 \\
\hline$N E^{c}$ & 10.49 & 10.48 & 10.47 & 10.20 & 9.92 \\
\hline SID Lys ${ }^{d}$ & 1.03 & 1.03 & 1.03 & 1.00 & 0.98 \\
\hline SID Lys/NE, g/MJ & 0.98 & 0.98 & 0.98 & 0.98 & 0.98 \\
\hline SID Thr/SID Lys & 0.65 & 0.65 & 0.65 & 0.65 & 0.65 \\
\hline SID Trp/SID Lys & 0.19 & 0.19 & 0.19 & 0.19 & 0.19 \\
\hline SID Val/SID Lys & 0.76 & 0.76 & 0.76 & 0.76 & 0.76 \\
\hline SID Leu/SID Lys & 1.20 & 1.28 & 1.35 & 1.32 & 1.44 \\
\hline SID Ile/SID Lys & 0.50 & 0.53 & 0.58 & 0.54 & 0.62 \\
\hline SID His/SID Lys & 0.35 & 0.40 & 0.45 & 0.41 & 0.47 \\
\hline SID Met + Cys/SID lys & 0.55 & 0.55 & 0.57 & 0.55 & 0.58 \\
\hline SID Phe + Tyr/SID Lys & 1.00 & 1.08 & 1.15 & 1.09 & 1.18 \\
\hline
\end{tabular}

${ }^{\mathrm{a} A}$ total of 175 pigs were used in an 28-d study. There were five pigs per pen and seven pens per treatment; SBM, soybean meal; EP-RSM, expelled press rapeseed meal; SE-RSM, solvent extracted rapeseed meal

${ }^{b}$ Vitamin-mineral premix supplied the following per kg of diet: vitamin A, 5,512 IU; vitamin $\mathrm{D}_{3}, 2,200 \mathrm{IU}$; vitamin E, $30 \mathrm{IU}$; vitamin $\mathrm{K}_{3}, 2.2 \mathrm{mg}$; vitamin $\mathrm{B}_{12}$, $27.6 \mu$ g;

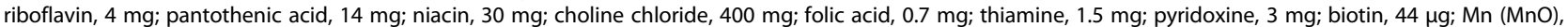
$40 \mathrm{mg} ; \mathrm{Fe}\left(\mathrm{FeSO}_{4} \cdot \mathrm{H}_{2} \mathrm{O}\right), 75 \mathrm{mg} ; \mathrm{Zn}(\mathrm{ZnO}), 75 \mathrm{mg} ; \mathrm{Cu}\left(\mathrm{CuSO}_{4} \cdot 5 \mathrm{H}_{2} \mathrm{O}\right), 100 \mathrm{mg} ; \mathrm{I}(\mathrm{KI}), 0.3 \mathrm{mg} ; \mathrm{Se}\left(\mathrm{Na}_{2} \mathrm{SeO}_{3}\right), 0.3 \mathrm{mg}$

${ }^{\mathrm{C}} \mathrm{DE}, \mathrm{ME}$ and NE calculated from values measured in Exp. 1

${ }^{\mathrm{d}}$ SID values were referenced from NRC (2012)

DM intake over the 5-d collection period from d 9 to 13. The energy lost in feces, urine and methane were measured for each animal on a given diet. The ME included energy lost as urine and methane. Energy lost as methane was calculated using a $39.54 \mathrm{~kJ} / \mathrm{L}$ conversion factor [14].

During d 9 to $\mathrm{d} 13$ of each period, $\mathrm{O}_{2}, \mathrm{CO}_{2}$, and $\mathrm{CH}_{4}$ concentrations in both ingoing and outgoing air, and outgoing air flow rates were measured at 5 min intervals. These concentrations were then used to calculate $\mathrm{O}_{2}$ consumption and $\mathrm{CO}_{2}$ and $\mathrm{CH}_{4}$ productions during each 5 min interval and these values were averaged and extrapolated to a $24 \mathrm{~h}$ period. Total heat production (THP) was then calculated for each day from gas exchanges and urinary loss of $\mathrm{N}$ according to Brouwer [14] using the following equation: 


$$
\begin{aligned}
\mathrm{THP}(\mathrm{kJ})= & 16.18 \times \mathrm{O}_{2}(\mathrm{~L})+5.02 \times \mathrm{CO}_{2}(\mathrm{~L})-2.17 \\
& \times \mathrm{CH}_{4}(\mathrm{~L})-5.99 \times \text { urinaryN }(\mathrm{g})
\end{aligned}
$$

Retention of energy (RE) was calculated according to the following equation:

$$
\operatorname{RE}(\mathrm{MJ} / \mathrm{d})=[\mathrm{ME} \text { intake }(\mathrm{MJ} / \mathrm{d})-\mathrm{THP}(\mathrm{MJ} / \mathrm{d})]
$$

Retention of energy as protein $\left(\mathrm{RE}_{\mathrm{P}}\right)$ was calculated from nitrogen balance and the retention of energy as lipid $\left(\mathrm{RE}_{\mathrm{L}}\right)$ corresponded to the difference between $R E$ and $R_{P}$ [10].

FHP was calculated using the equation used for THP with gas concentrations and air flow obtained from only the last 8-h heat production measurement on d 16 (ie, from 2230 to $0630 \mathrm{~h}$ or started $31 \mathrm{~h}$ after the last maintenance meal) [9]. In order to base production using the same time span as used for THP, the 8-h heat production was extrapolated to a 24-h period. Net energy of each diet was calculated according to Noblet et al. [15]

$$
\mathrm{NE}(\mathrm{kJ} / \mathrm{kg} \mathrm{DM})=[\mathrm{RE}(\mathrm{kJ} / \mathrm{d})+\mathrm{FHP}(\mathrm{kJ} / \mathrm{d})] / \text { DM intake }(\mathrm{kg} / \mathrm{d})
$$

The FHP value obtained on the fasting day $[\mathrm{kJ} /(\mathrm{kg}$ $\left.\left.\mathrm{BW}^{0.6} \cdot \mathrm{d}\right)\right]$ was used during the fed days according to the estimated average BW over the fed days.

The DM of ingredients was measured prior to the preparation of diets in order to calculate the DM ratio of each test ingredient in the diet. The DE, ME and NE of the corn was calculated using direct method. The percentage minerals and vitamins in the corn diet was $2.79 \%$ (DM basis) and was not a source of energy; therefore, the energy values of the corn and amino acids were divided by 0.9721 ; the energy of corn per se was calculated by subtracting the energy of amino acids (Evapig). The difference method was used to calculate the average GE, DE, ME and NE contributions of soybean meal assuming that the average GE, DE, ME and NE values of the corn and amino acids mixture estimated from the corn diet were applicable to the corn-soybean meal diet [16]. The DE/GE, ME/DE and NE/ME ratios could then be calculated for soybean meal from these calculated GE, $\mathrm{DE}, \mathrm{ME}$ and $\mathrm{NE}$ values and used to estimate the final $\mathrm{DE}$, $M E$ and NE values as the product of measured GE and $\mathrm{DE} / \mathrm{GE}$ for $\mathrm{DE}$, measured $\mathrm{GE}$ and $\mathrm{DE} / \mathrm{GE}$ and ME/DE for $\mathrm{ME}$ and measured GE and DE/GE and ME/DE and NE/ ME for NE. All calculations were done on a DM basis. Similarly, the corn-soybean meal diet was used as the basal diet when the energy of rapeseed meal was calculated according to the difference method. The apparent total tract digestibility (ATTD) of nutrients in diets was calculated according to the methods of Noblet et al. [15]. The respiratory quotient (RQ) corresponds to the ratio between $\mathrm{CO}_{2}$ production and $\mathrm{O}_{2}$ consumption.

In Exp. 2, all pigs were weighed on d 1and d 29 to determine average daily gain (ADG), average daily feed intake (ADFI) and gain to feed ratio (G:F). The caloric efficiency of dietary energy was calculated as ADFI $(\mathrm{kg} /$ d) $\times$ Diet energy content $(\mathrm{MJ} / \mathrm{kg}) / \mathrm{ADG}(\mathrm{kg} / \mathrm{d})$ with energy content expressed as DE, ME or NE.

\section{Statistical analysis}

Data from Exp. 1 were analyzed using PROC MIXED (SAS Inst. Inc., Cary, NC, USA) with diet as fixed effects and period and chamber as random effects. When the Ftest for diet treatment was significant, differences between dietary treatments were tested among least square means using Tukey's least significant difference. Data in Exp. 2 were analyzed using MIXED procedure of SAS for a completely randomized design with fixed effects of treatment and pen as the experiment unit. In all analyses, the differences were considered significant if $P<0.05$, and considered as a trend at $P<0.10$.

\section{Results}

\section{Chemical composition of rapeseed meal}

The percentage of EE in EP-RSM was greater than in SE-RSM (9.5\% vs. $1.1 \%$ ), while the CP content in the EPRSM was lower than in the SE-RSM (39.2\% vs. $42.4 \%)$. The NDF content in the EP-RSM was greater than in SE-RSM (37.0\% vs. 30.8\%). These two rapeseed meals contained similar proportions of amino acids. The composition of the four diets is in agreement with the ingredients percentages and their composition with the lowest $\mathrm{CP}$ content in the corn diet and the highest $\mathrm{CP}$ contents in the rapeseed meal diets. Finally, the EE content was higher in the EP-RSM diet.

\section{Exp.1: Net energy experiment}

The ATTD of DM, OM and GE was similar in the corn and corn-soybean meal diets, which values were greater than in the two rapeseed meal diets (Table 4, 90.2\% vs. 86.6\% for ATTD of DM, $90.3 \%$ vs. $87.0 \%$ for ATTD of OM, $88.3 \%$ vs. $85.1 \%$ for ATTD of GE; $P<0.01$ ). However, the ATTD of CP was similar in the corn-soybean meal diet and the two rapeseed meal diets, these values being greater than in the corn diet in connection with its lower CP content $(86.4 \%$ vs. $79.9 \% ; P<0.01)$.

The nitrogen intake increased with the $\mathrm{CP}$ content in the diet $(P<0.01)$. The nitrogen output from feces and urine was similar in the corn-soybean meal diet and the corn diet but lower than in the two rapeseed meal diets $(P<0.01)$. Consequently, the urinary energy as a percentage of DE was greater in the SE-RSM diet than in the corn-soybean meal diet, and the lowest in the corn diet $(P<0.01)$. These led to ME to DE ratio greater in the corn diet than in the corn-soybean meal diet, and the lowest in the SE-RSM diet $(P<0.01)$.

The retention of nitrogen was similar in the two rapeseed meal diets and the corn-soybean diet, which was 
Table 4 Effect of diet characteristics on energy and nitrogen balances of growing pigs (Exp. 1)

\begin{tabular}{|c|c|c|c|c|c|c|}
\hline Item & Corn & SBM & EP-RSM & SE-RSM & SEM & $P$-value \\
\hline $\mathrm{BW}, \mathrm{kg}$ & $40.2^{b}$ & $44.0^{\mathrm{a}}$ & $44.1^{a}$ & $44.1^{a}$ & 0.9 & 0.01 \\
\hline DM intake, kg/d & 1.33 & 1.34 & 1.37 & 1.40 & 0.02 & 0.07 \\
\hline \multicolumn{7}{|l|}{ Digestibility coefficients, \% } \\
\hline DM & $90.4^{\mathrm{a}}$ & $90.0^{\mathrm{a}}$ & $87.3^{b}$ & $85.8^{\mathrm{b}}$ & 0.7 & $<0.01$ \\
\hline $\mathrm{CP}$ & $79.9^{b}$ & $88.0^{\mathrm{a}}$ & $86.2^{\mathrm{a}}$ & $85.1^{\mathrm{a}}$ & 1.3 & $<0.01$ \\
\hline $\mathrm{OM}$ & $90.4^{\mathrm{a}}$ & $90.2^{\mathrm{a}}$ & $87.7^{b}$ & $86.3^{b}$ & 0.7 & $<0.01$ \\
\hline GE & $88.2^{\mathrm{a}}$ & $88.3^{\mathrm{a}}$ & $86.2^{\mathrm{ab}}$ & $84.0^{\mathrm{b}}$ & 0.8 & $<0.01$ \\
\hline \multicolumn{7}{|l|}{ Nitrogen balance, g/d } \\
\hline Intake & $19.9^{d}$ & $37.0^{c}$ & $46.9^{b}$ & $50.4^{\mathrm{a}}$ & 0.6 & $<0.01$ \\
\hline Fecal output & $4.0^{\mathrm{b}}$ & $4.5^{\mathrm{b}}$ & $6.6^{\mathrm{a}}$ & $7.5^{\mathrm{a}}$ & 0.5 & $<0.01$ \\
\hline Urinary output & $6.6^{\mathrm{b}}$ & $10.6^{\mathrm{ab}}$ & $15.5^{\mathrm{a}}$ & $15.4^{\mathrm{a}}$ & 1.4 & $<0.01$ \\
\hline Retention & $9.4^{b}$ & $21.9^{\mathrm{a}}$ & $24.8^{\mathrm{a}}$ & $27.5^{\mathrm{a}}$ & 1.2 & $<0.01$ \\
\hline \multicolumn{7}{|l|}{ Energy utilization, \% } \\
\hline Urinary energy $\%$ of $\mathrm{DE}$ & $1.8^{\mathrm{c}}$ & $2.7^{b}$ & $3.4^{\mathrm{ab}}$ & $3.9^{\mathrm{a}}$ & 0.25 & $<0.01$ \\
\hline Methane energy, \% DE & 0.4 & 0.7 & 0.4 & 0.6 & 0.08 & 0.06 \\
\hline ME/DE & $97.8^{\mathrm{a}}$ & $96.6^{b}$ & $96.2^{\mathrm{bc}}$ & $95.5^{c}$ & 0.27 & $<0.01$ \\
\hline NE/ME & 78.2 & 76.5 & 76.3 & 76.7 & 0.82 & 0.16 \\
\hline \multicolumn{7}{|c|}{ Energy balance, $\mathrm{kJ} /\left(\mathrm{kg} \mathrm{BW} \mathrm{B}^{0.6} \cdot \mathrm{d}\right)$} \\
\hline ME intake, & $2,273^{a}$ & $2,160^{\mathrm{bc}}$ & $2,195^{b}$ & $2,120^{c}$ & 28 & $<0.01$ \\
\hline THP & 1,259 & 1,308 & 1,268 & 1,250 & 25 & 0.15 \\
\hline $\mathrm{THPC}^{2}$ & 1,232 & 1,317 & 1,265 & 1,271 & 22 & 0.08 \\
\hline $\mathrm{RE}_{\mathrm{P}}^{3}$ & $152^{c}$ & $337^{b}$ & $381^{\mathrm{ab}}$ & $424^{a}$ & 20 & $<0.01$ \\
\hline $\mathrm{RE}_{\mathrm{L}}^{4}$ & $862^{\mathrm{a}}$ & $516^{b}$ & $546^{\mathrm{b}}$ & $446^{\mathrm{b}}$ & 34 & $<0.01$ \\
\hline RE & $1,014^{\mathrm{a}}$ & $852^{b}$ & $928^{b}$ & $870^{b}$ & 27 & $<0.01$ \\
\hline FHP & 769 & 809 & 756 & 766 & 22 & 0.18 \\
\hline \multicolumn{7}{|l|}{$\mathrm{RQ}$} \\
\hline Fed state & $1.11^{\mathrm{a}}$ & $1.05^{b}$ & $1.02^{b}$ & $1.03^{b}$ & 0.01 & $<0.01$ \\
\hline Fasted state & 0.77 & 0.77 & 0.78 & 0.78 & 0.01 & 0.07 \\
\hline \multicolumn{7}{|l|}{ Energy values, MJ/kg DM } \\
\hline $\mathrm{DE}$ & $15.98^{\mathrm{a}}$ & $16.10^{\mathrm{a}}$ & $16.14^{\mathrm{a}}$ & $15.42^{\mathrm{b}}$ & 0.14 & $<0.01$ \\
\hline ME & $15.64^{\mathrm{a}}$ & $15.56^{\mathrm{a}}$ & $15.52^{\mathrm{a}}$ & $14.73^{b}$ & 0.13 & $<0.01$ \\
\hline NE & $12.23^{\mathrm{a}}$ & $11.90^{\mathrm{a}}$ & $11.84^{\mathrm{ab}}$ & $11.30^{\mathrm{b}}$ & 0.15 & $<0.01$ \\
\hline
\end{tabular}

${ }^{1} \mathrm{~A}$ total 24 pigs were allotted to 1 of 4 dietary treatments with six pigs per diet and four periods, $16 \mathrm{~d}$ per period; SBM, soybean meal; EP-RSM, expelled press rapeseed meal; SE-RSM, solvent extracted rapeseed meal

${ }^{2} \mathrm{THPc}$ means that total heat production was adjusted for comparable ME intake by covariance

${ }^{3} R_{\mathrm{P}}=$ Energy retention as protein $\left[\mathrm{kJ} /\left(\mathrm{kg} \mathrm{BW}{ }^{0.6} \cdot \mathrm{d}\right)\right]=[\mathrm{N}$ intake $(\mathrm{g})-\mathrm{N}$ in feces $(\mathrm{g})-\mathrm{N}$ in urine $(\mathrm{g})] \times 6.25 \times 23.86(\mathrm{~kJ} / \mathrm{g}) / \mathrm{BW}^{0.6}$

${ }^{4} \mathrm{RE}_{\mathrm{L}}=$ Energy retention as fat $\left.\left[\mathrm{kJ} / \mathrm{kg} \mathrm{BW}{ }^{0.6} \cdot \mathrm{d}\right)\right]=[\mathrm{RE}(\mathrm{kJ})$ - energy retention as protein $(\mathrm{kJ})] / \mathrm{BW}^{0.6}$

${ }^{a b c d}$ Means in the same row with differing superscripts differ $(P<0.05)$

markedly greater than in the corn diet (24.7 vs. $9.4 \mathrm{~g}$ per day, $P<0.01)$. Methane energy averaged $0.54 \%$ of $\mathrm{DE}$ and it tended to be greater in the SE-RSM diet than in the EPRSM diet $(P=0.07)$.

Compared to the pigs fed the rapeseed meal diet, the pigs fed the corn-soybean meal diet had a comparable ME intake while the pigs fed the corn diet had the greatest ME intake. There was little difference in THP (average: $\left.1,270 \mathrm{~kJ} /\left(\mathrm{kg} \quad \mathrm{BW}^{0.6} \cdot \mathrm{d}\right)\right)$ between diets despite differences in ME intake. However, it tended to be lower in the corn diet when THP was adjusted for similar ME intake (Table 4). Consequently, the pigs fed the corn diet had the greatest RE compared to other diets $(1,014 \mathrm{vs}$. $\left.883 \mathrm{~kJ} /\left(\mathrm{kg} \mathrm{BW}^{0.6} \cdot \mathrm{d}\right), P<0.01\right)$. In connection with their lower nitrogen gain and their higher $\mathrm{RE}$, the greatest $\mathrm{RE}_{\mathrm{L}}$ was found in the pigs fed the corn diet. The mean FHP was $775 \mathrm{~kJ} /\left(\mathrm{kg} \mathrm{BW}^{0.6} \cdot \mathrm{d}\right)$ and was not affected by diet composition $(P=0.19)$. The RQ was the greatest in 
the corn diet $(P<0.01)$ in connection with the higher $\mathrm{RE}_{\mathrm{L}}$. There was no difference in NE to ME ratio among the four diets $(P=0.18)$ despite difference in chemical composition. Lower energy values (DE, $\mathrm{ME}$ and $\mathrm{NE}$ ) were observed in the SE-RSM diets compared to the other diets that had comparable energy values.

The ingredients values calculated from the diets values are shown in Table 5. The ATTD of CP, OM and GE of the four ingredients were quite variable with the lowest value for SE-RSM. The ATTD of OM of the corn was the greatest. Compared to other ingredients, the corn had the greatest ME to DE ratio (97.8\%) and NE to ME ratio (78.4\%), while the SE-RSM had the least ME to DE ratio (90.7\%); the soybean meal had the lowest NE to ME ratio (70.2\%). The NE of corn, soybean meal, EP-RSM and SE-RSM diets were $12.46,11.34,11.71$ and $8.83 \mathrm{MJ} / \mathrm{kg} \mathrm{DM}$, respectively.

\section{Exp.2: Growth performance experiment}

During the 28 days period, the NE intake averaged $21.15 \mathrm{MJ} / \mathrm{d}$ and was similar for the five diets. Similarly, final BW, ADG, ADFI and G:F did not change with the inclusion of EP-RSM or SE-RSM in the diets (Table 6). The mean caloric efficiencies of DE, ME and NE for BW gain were $31.5,30.3$ and $23.1 \mathrm{MJ} / \mathrm{kg}$, respectively and were not affected by diet characteristics $(P>0.10)$.

\section{Discussion}

In the current experiment, the two rapeseed meals are not from the same batch. Therefore, we can't evaluate the oil extraction processing and its impact on the composition of the non-fat fraction of the meal. However, the lower CP in the high fat RSM is consistent with the dilution effect of residual oil. Overall, the chemical composition and amino acids contents of the four

Table 5 Energy utilization and energy value of the four ingredients (Exp. 1) ${ }^{\mathrm{a}}$

\begin{tabular}{lcccc}
\hline Item & Corn & SBM & EP-RSM & SE-RSM \\
\hline \multicolumn{2}{l}{ Digestibility coefficients, \% } & & & \\
CP & 82.4 & 94.8 & 81.6 & 78.9 \\
OM & 93.1 & 90.5 & 76.4 & 68.0 \\
GE & 88.2 & 89.8 & 77.6 & 65.6 \\
Energy utilization, \% & & & \\
ME/DE & 97.8 & 92.1 & 94.9 & 90.7 \\
NE/ME & 78.3 & 70.2 & 74.7 & 76.5 \\
NE/DE & 76.6 & 64.6 & 71.0 & 69.4 \\
Energy values, MJ/kg DM & & & \\
DE & 16.27 & 17.51 & 16.55 & 12.82 \\
ME & 15.92 & 16.10 & 15.71 & 11.61 \\
NE & 12.46 & 11.34 & 11.71 & 8.83 \\
\hline
\end{tabular}

${ }^{a}$ There were six pigs per treatment; SBM, soybean meal; EP-RSM, expelled press rapeseed meal; SE-RSM, solvent extracted rapeseed meal ingredients are within the range of values reported in our previous work $[2,3,17,18]$. However, the NDF content (33.9\% DM basis) in the two rapeseed meals was greater than the values published by Sauvant et al. (31.9\% DM basis) [19] and NRC (25.2\% DM basis) [20].

As in other literature studies [21,22], the digestibility of $\mathrm{DM}, \mathrm{OM}$ and GE were lower in the rapeseed meal diets in connection with their higher NDF content. But this negative effect of dietary fiber from RSM is attenuated in the EP-RSM diet in connection with its high and digestible oil fraction. This resulted in similar digestibility of GE between the EP-RSM and corn-soybean meal diets. These results are also found in the four ingredients with the lowest digestibility DM, OM and GE in the SE-RSM in connection with its high NDF content.

The ME to DE ratio was lower in the rapeseed diets in connection with their high urinary nitrogen output due to the high $\mathrm{CP}$ in the rapeseed diets, which also confirmed the result that $\mathrm{CP}$ is negatively correlated with ME to DE ratio [15]. The methane energy measured in our study is consistent with data obtained in similar body weight pigs $[9,10,15]$ and indicates that the methane energy loss in growing pigs is little variable with differences in diets composition.

The THP values measured in the current experiment are in agreement with the range of THP observed at comparable ME intakes for 61 diets by Noblet et al. [15]. In the current experiment, in order to eliminate the effect of ME intake, the THP was adjusted for comparable ME intakes by covariance. In this way, the THP for the corn diet became lower in connection with the high starch content of the diet and also the higher proportion of energy retained as fat, which is fully consistent with the rather high efficiency of starch for NE [15] and the higher efficiency for fat gain than for protein gain [23]. In the current experiment, the value of FHP (average: $\left.775 \mathrm{~kJ} /\left(\mathrm{kg} \mathrm{BW}^{0.6} \cdot \mathrm{d}\right)\right)$ was estimated as the nocturnal heat production after a period of feed deprivation of $31 \mathrm{~h}$. The value is remarkably close to our previous work using the same method $[10,24,25]$ and the results of Noblet et al. [15]. In addition, in agreement with other literature data $[10,26,27]$, the FHP was not affected by diet composition (dietary $\mathrm{CP}$ or $\mathrm{EE}$ ).

In the current Exp.1, the corn diet was supplemented with essential AA to meet the optimal amino acids balance, however, the daily supply was insufficient and the nitrogen gain and $R E_{\mathrm{P}}$ are lower. In addition, $\mathrm{RE}$ was higher than in the other diets and $\mathrm{RE}_{\mathrm{L}}$ was then higher in the corn diet. However, we supplemented corn with free AA in order to attenuate this effect of shortage of $\mathrm{AA}$ and $\mathrm{CP}$. In this way, the energy value (ME and $\mathrm{NE}$ ) of corn measured in the Exp.1 could be representative of normal situations where corn is used with optimal levels of essential AA (Exp.2). 
Table 6 Effect of rapeseed meal on growing pigs performance (Exp.2)

\begin{tabular}{|c|c|c|c|c|c|c|c|}
\hline \multirow[t]{2}{*}{ Item } & \multirow[t]{2}{*}{ Basal } & \multicolumn{2}{|c|}{ EP-RSM ${ }^{\mathrm{b}}$} & \multicolumn{2}{|c|}{ SE-RSM ${ }^{c}$} & \multirow[t]{2}{*}{ SEM } & \multirow[t]{2}{*}{$P$-value } \\
\hline & & $10 \%$ & $20 \%$ & $10 \%$ & $20 \%$ & & \\
\hline Initial BW, kg & 35.9 & 36.0 & 36.1 & 36.1 & 36.1 & 2.0 & 0.99 \\
\hline Final BW, kg & 62.0 & 62.2 & 61.3 & 61.0 & 61.5 & 2.4 & 0.99 \\
\hline$A D F I, g / d$ & 2,093 & 2,059 & 1,996 & 2,019 & 2,086 & 75 & 0.86 \\
\hline$A D G, g / d$ & 929 & 937 & 901 & 891 & 910 & 24 & 0.64 \\
\hline G:F & 0.446 & 0.458 & 0.454 & 0.442 & 0.436 & 0.010 & 0.71 \\
\hline NE intake, MJ/d & 21.96 & 21.58 & 20.91 & 20.60 & 20.69 & 0.78 & 0.68 \\
\hline \multicolumn{8}{|c|}{ Caloric efficiency, MJ/kg } \\
\hline $\mathrm{DE}$ & 31.93 & 31.24 & 31.60 & 31.47 & 31.16 & 0.72 & 0.95 \\
\hline ME & 30.80 & 30.10 & 30.39 & 30.21 & 29.77 & 0.70 & 0.88 \\
\hline $\mathrm{NE}$ & 23.60 & 23.00 & 23.16 & 23.13 & 22.78 & 0.53 & 0.86 \\
\hline
\end{tabular}

${ }^{a}$ A total of 175 pigs were used in an 28-d study. There were five pigs per pen and seven pens per treatment

${ }^{b}$ EP-RSM, expelled press rapeseed meal

${ }^{\mathrm{C}} \mathrm{SE}-\mathrm{RSM}$, solvent extracted rapeseed meal

The soybean meal had the lowest NE to ME ratio, while the corn had the greatest NE to ME ratio. This indicates that the efficiency of utilization of ME for $\mathrm{NE}$ depends on chemical composition [27]. The NE to ME ratio of corn is also similar to the value in Sauvant et al. $(78.3 \%$ vs. 80.1\%) [28]. However, the NE to ME ratio of soybean meal and rapeseed meal obtained in the present trial are greater (70.2\% vs. $60.5 \%$ for soybean meal; $76.5 \%$ vs. $59.7 \%$ for rapeseed meal) than the values in Sauvant et al. [28]. The difference in NE to ME ratio may be explained by the slightly greater FHP measured in the current experiment than value used by Sauvant et al. [28] (775 vs. $\left.750 \mathrm{~kJ} /\left(\mathrm{kg} \mathrm{BW}^{0.6} \cdot \mathrm{d}\right)\right)$.

The DE and ME values of the four ingredients measured in the current experiment are similar to those obtained in our previous studies $[2,3,17,18]$. In agreement with the values of NE to ME ratio in the present study and in Sauvant et al. [28], the NE value of corn measured in Exp. 1 is similar to the value in Sauvant et al. [28]. But the NE values of soybean meal and rapeseed meal are greater than the table values in Sauvant et al. (11.34 vs. $9.22 \mathrm{MJ} / \mathrm{kg}$ DM for SBM, 8.83 vs. $7.14 \mathrm{MJ} / \mathrm{kg}$ DM for SE-RSM) [28]. The $\mathrm{NE}$ contents in corn, soybean meal were similar to the values reported by Liu et al. (12.46 vs. $13.21 \mathrm{MJ} / \mathrm{kg}$ DM for corn, 11.34 vs. $10.62 \mathrm{MJ} / \mathrm{kg}$ DM for SBM) [24] using the same methodology. The NE content in SE-RSM measured using indirect calorimetry by Heo et al. ( 8.83 vs. $8.80 \mathrm{MJ} / \mathrm{kg}$ DM) [29] was similar to the value in the present experiment. The greater NE value found in EP-RSM than in SERSM is associated with its high EE value, which was in agreement with the results by Woyengo et al. [30].

In the growth trial, diets were supplemented with crystalline amino acids in order to maintain a constant SID Lys/NE ratio $(0.98 \mathrm{~g} / \mathrm{MJ})$ and balanced for the other essential amino acids. Therefore, the efficiencies of energy for BW gain were calculated without the confounding effect of amino acids deficiency. Several research projects reported that there was no impairment of pig performance when EP-RSM or SE-RSM replaced soybean meal in growing pig diets formulated to equal NE and SID amino acids [31, 32], or that contained equal quantities of digestible $\mathrm{CP}$ and digestible amino acids [4]. In the current experiment, we also failed to detect any statistically significant differences in growth performance with increasing inclusion rates of EP-RSM or SE-RSM.

In the current research, we used the same ingredients (corn, soybean meal, EP-RSM and SE-RSM) in the two experiments. Therefore, the NE of the five diets in Exp.2 was calculated according to the values measured in Exp. 1. Increasing inclusion level of EP-RSM or SE-RSM did not affect caloric efficiency of NE, which indicated that the NE value measured in Exp.1 by indirect calorimetry was close to the actual value as indicated by the caloric efficiency results in Exp. 2. In the growth trial (Exp. 2), we also failed to detect any statistically significant differences in caloric efficiency of DE and ME with increasing inclusion rates of EP-RSM or SE-RSM. Therefore, these data do not show any advantage of NE system on DE or ME systems. In fact, the diets in the growth trial were very similar in terms of chemical composition, energy value, $\mathrm{CP}$ and $\mathrm{AA}$ contents with then little expected differences in ME/DE and NE/ME ratios. Furthermore, our research to measure the caloric efficiency of NE was only according to ADG. This should also be adjusted for differences in BW gain composition (lipid or fat contents) for being more accurate.

\section{Conclusions}

The DE, ME and NE values in EP-RSM were greater than values in SE-RSM. The efficiency of utilization of ME for NE depends on chemical composition. The NE values measured in Exp.1 are confirmed by results of Exp. 2 with comparable caloric efficiencies of $\mathrm{NE}$ for all diets. 


\section{Appendix}

Table 7 Design of net energy experiment (Exp.1)

\begin{tabular}{|c|c|c|c|c|c|c|c|}
\hline & Chambers & $\mathrm{A} 1$ & $\mathrm{~A} 2$ & $\mathrm{~B} 1$ & B2 & $\mathrm{Cl}$ & $\mathrm{C} 2$ \\
\hline \multirow[t]{2}{*}{ Period 1} & Diets & 1 & $\|$ & III & IV & 1 & $\overline{\|}$ \\
\hline & Pigs & 1 & 2 & 3 & 4 & 5 & 6 \\
\hline \multirow[t]{2}{*}{ Period 2} & Diets & $\|$ & III & IV & 1 & $\|$ & III \\
\hline & Pigs & 7 & 8 & 9 & 10 & 11 & 12 \\
\hline \multirow[t]{2}{*}{ Period 3} & Diets & III & IV & I & $\|$ & III & IV \\
\hline & Pigs & 13 & 14 & 15 & 16 & 17 & 18 \\
\hline \multirow[t]{2}{*}{ Period 4} & Diets & IV & I & $\|$ & III & IV & I \\
\hline & Pigs & 19 & 20 & 21 & 22 & 23 & 24 \\
\hline
\end{tabular}

\section{Abbreviations}

AA: Amino acid; ADF: Acid detergent fiber; ADFl: Average daily feed intake; ADG: Average daily gain; ATTD: Apparent total tract digestibility; BW: Body weight; CP: Crude protein; DE: Digestible energy; DM: Dry matter; EE: Ether extract; EP-RSM: Expeller-pressed rapeseed meal; F:G: Gain to feed ratio FHP: Fasting heat production; GE: Gross energy; HP: Heat production; ME: Metabolizable energy; N: Nitrogen; NDF: Neutral detergent fiber; NE: Net energy; OM: Organic matter; RE: Retention energy; $R E_{L}$ : Retention energy as lipid; $R E_{p}$ : Retention energy as protein; RQ: Respiratory quotient; SEM: Standard error of the mean; SE-RSM: Solvent-extracted rapeseed meal; SID: Standard ileal digestibility; THP: Total heat production

\section{Acknowledgements}

This project was financially supported by the Modern Agricultural Industry Technology System (CARS-36), Developing key equipment for digital management and monitoring environment in animal production (2013AA10230602), National Natural Science Foundation of China (31372317) and the 111 Project (B16044). I would like to express my heartfelt gratitude to Dr. Michael A. Brown for helping me edit the paper.

Submitting author: Zhongchao Li: No.2, Yuanminyuan west road, Haidian district, China Agricultural University, Beijing 100193, China.

\section{Funding}

This project was financially supported by the Modern Agricultural Industry Technology System (CARS-36), Developing key equipment for digital management and monitoring environment in animal production (2013AA10230602), National Natural Science Foundation of China (31372317) and the 111 Project (B16044). The funders had no role in study design, data collection and analysis, decision to publish, or preparation of the manuscript.

\section{Availability of data and materials}

All the data were presented in the main manuscript and available to readers.

\section{Authors' contributions}

$\mathrm{ZCL}$ carried out the animal trial, performed the statistics and drafted the manuscript. YKL, ZQL, HL and JBZ participated in the experiments. JN, CHL, FLW and DFL critically evaluated the manuscript. All authors read and approved the final manuscript.

\section{Competing interests}

The authors declare that they have no competing interests.

\section{Consent for publication}

Not applicable.

\section{Ethics approva}

All procedures used in this study were performed according to the guidelines for the ethical treatment of animal by the Institutional Animal Care and Use Committee of China Agricultural University (Beijing, China).

\section{Author details}

'State Key Laboratory of Animal Nutrition, Ministry of Agriculture Feed Industry Centre, China Agricultural University, No. 2, Yuanminyuan west road, Haidian district, Beijing 100193, China. ${ }^{2}$ INRA, UMR Pegase, 35590 Saint-Gilles, France.

Received: 13 December 2016 Accepted: 8 April 2017

Published online: 01 May 2017

\section{References}

1. USDA: Oilseeds: World markets and trade, USDA Foreign Agricultural Service. http://apps.fas.usda.gov/psdonline/circulars/production.pdf. Accessed 18 Sept 2016.

2. Li PL, Wang FL, Wu F, Wang JR, Liu L, et al. Chemical composition, energy and amino acid digestibility in double-low rapeseed meal fed to growing pigs. J Anim Sci Biotechnol. 2015;6:37-47.

3. Li PL, Wu F, Chen YF, Wang JR, Guo PP, Li ZC, et al. Determination of the energy content and amino acid digestibility of double-low rapeseed cakes fed to growing pigs. Anim Feed Sci Technol. 2015;210:243-53.

4. Little KL, Bohrer BM, Maison T, Liu YH, Stein HH, Boler DD. Effects of feeding canola meal from high-protein or conventional varieties of canola seeds on growth performance, carcass characteristics, and cutability of pigs. J Anim Sci. 2015;93:1284-97.

5. Graham AB, Goodband RD, Tokach MD, Dritz SS, DeRouchey JM, Nitikanchana S. The effects of medium-oil dried distillers grains with solubles on growth performance, carcass traits, and nutrient digestibility in growing-finishing pigs. J Anim Sci. 2014;92:604-11.

6. Graham AB, Goodband RD, Tokach MD, Dritz SS, DeRouchey JM, Nitikanchana S, et al. The effects of low-, medium-, and high-oil distillers dried grains with solubles on growth performance, nutrient digestibility, and fat quality in finishing pigs. J Anim Sci. 2014;92:3610-23.

7. De Jong JA, DeRouchey JM, Tokach MD, Dritz SS, Goodband RD. Effects of dietary wheat middlings, corn dried distillers grains with solubles, and net energy formulation on nursery pig performance. J Anim Sci. 2014;92:3471-81.

8. Adeola O, Mahan DC, Azain MJ, Baidoo SK, Cromwell GL, Hill GM, et al. Dietary lipid sources and levels for weanling pigs. J Anim Sci. 2013;91:4216-25.

9. Zhang GF, Liu DW, Wang FL, Li DF. Estimation of the net energy requirements for maintenance in growing and finishing pigs. J Anim Sci. 2014:92:2987-95.

10. Li ZC, Li P, Liu DW, Li DF, Wang FL, Su YB, et al. Determination of the energy value of corn distillers dried grains with solubles containing different oil levels in growing pigs. J Anim Physiol Anim Nutr. 2015. doi:10.1111/jpn. 12445.

11. AOAC Official Methods of Analysis. 18th ed. Arlington: Association of Official Chemists; 2007

12. Thiex NJ, Anderson S, Gildemeister B. Crude fat, diethyl exther extraction in feed, cereal grains, and forge: Collaborative study. J AOAC Int. 2003:86:888-98.

13. Van Soest PJ, Robertson JB, Lewis BA. Methods for dietary fiber, neutral detergent fiber, and nonstarch polysaccharides in relation to animal nutrition. J Dairy Sci. 1991;74:3583-97. 
14. Brouwer E. Report of sub-committee on constants and factors. Proceedings of the 3rd EAAP Symposium on Energy Metabolism; Troonn, Publ. 11. London: Academic; 1965. p. 441-3.

15. Noblet J, Fortune $H$, Shi XS, Dubois S. Prediction of net energy value of feeds for growing pigs. J Anim Sci. 1994;72:344-54.

16. Adeola O. Digestion and balance techniques in pigs. In: Lewis AJ, Southern LL, editors. Swine nutrition. New York: CRC Press; 2001. p. 903-16.

17. Li Q, Zang J, Liu DW, Piao XS, Lai CH, Li DF. Predicting corn digestible and metabolizable energy content from its chemical composition in growing pigs. J Anim Sci Biotechnol. 2014;5:11-9.

18. Li ZC, Wang XX, Guo PP, Liu L, Piao XS, Stein HH, et al. Prediction of digestible and metabolisable energy in soybean meal produced from soybeans of different origins fed to growing pigs. Arch Anim Sci. 2015;69:473-86.

19. Sauvant D, Perez JM, Tran G. Tables of composition and nutritional value of feed materials: pigs, poultry, cattle, sheep, goats, rabbits, horses and fish. Wageningen Academic Pub; 2004.

20. NRC. Nutrient requirements of swine. 11th ed. Washington: National Academy Press; 2012.

21. Noblet J, Le Goff G. Effect of dietary fibre on the energy value of feeds for pigs. Anim Feed Sci Technol. 2001;90:35-52.

22. Le Goff G, Dubois S, van Milgen J, Noblet J. Influence of dietary fibre level on digestive and metabolic utilization of energy in growing and finishing pigs. Anim Res. 2002;51:245-60.

23. Noblet J, Karege C, Dubois S, van Milgen J. Metabolic utilization of energy and maintenance requirements in growing pigs: effects of sex and genotype. J Anim Sci. 1999;77:1208-16.

24. Liu DW, Jaworski NW, Zhang GF, Li ZC, Li DF, Wang FL. Effect of experimental methodology on fasting heat production and the net energy content of corn and soybean meal fed to growing pigs. Arch Anim Nutr. 2014;68:281-95

25. Liu DW, Liu L, Li DF, Wang FL. Determination and prediction of the net energy content of seven feed ingredients fed to growing pigs based on chemical composition. Anim Prod Sci. 2015;55:1152-63.

26. Le Bellego L, Van Milgen J, Dubois S, Noblet J. Energy utilization of low-protein diets in growing pigs. J Anim Sci. 2001;79:1259-71.

27. Noblet J, Le Bellego L, Van Milgen J, Dubois S. Effects of reduced dietary protein level and fat addition on heat production and nitrogen and energy balance in growing pigs. Anim Res. 2001;50:227-38.

28. Sauvant D, Perez J M, Tran G. 2004. Tables of composition and nutritional value of feed materials: pigs, poultry, cattle, sheep, goats, rabbits, horses and fish. Wageningen Academic Pub.

29. Heo JM, Adewole D, Nyachoti M. Determination of the net energy content of canola meal from Brassica napus yellow and Brassica juncea yellow fed to growing pigs using indirect calorimetry. Anim Sci J. 2014;85:751-56

30. Woyengo TA, Sánchez JE, Yánez J, Beltranena E, Cervantes M, Morales A, et al. Nutrient digestibility of canola co-products for grower pigs. Anim Feed Sci Technol. 2016;222:7-16.

31. Landero JL, Beltranena E, Cervantes M, Morales A, Zijlstra RT. The effect of feeding solvent-extracted canola meal on growth performance and diet nutrient digestibility in weaned pigs. Anim Feed Sci Technol. 2011;170:136-40.

32. Landero JL, Beltranena E, Cervantes M, Araiza AB, Zijlstra RT. The effect of feeding expeller-pressed canola meal on growth performance and diet nutrient digestibility in weaned pigs. Anim Feed Sci Technol. 2012;171:240-5.

\section{Submit your next manuscript to BioMed Central and we will help you at every step:}

- We accept pre-submission inquiries

- Our selector tool helps you to find the most relevant journal

- We provide round the clock customer support

- Convenient online submission

- Thorough peer review

- Inclusion in PubMed and all major indexing services

- Maximum visibility for your research

Submit your manuscript at www.biomedcentral.com/submit

) Biomed Central 